\title{
PENGARUH INTELLECTUAL CAPITAL DAN UKURAN PERUSAHAAN TERHADAP KINERJA KEUANGAN PERUSAHAAN
}

\author{
Herni Kurniawati ${ }^{1}$, Rosmita Rasyid ${ }^{2}$, Fanny Andriani Setiawan ${ }^{3}$ \\ ${ }^{1}$ Fakultas Ekonomi dan Bisnis, Universitas Tarumanagara Jakarta \\ Email: hernik@fe.untar.ac.id \\ ${ }^{2}$ Fakultas Ekonomi dan Bisnis, Universitas Tarumanagara Jakarta \\ Email: rosmitar@fe.untar.ac.id \\ ${ }^{3}$ Fakultas Ekonomi dan Bisnis, Universitas Tarumanagara Jakarta \\ Email: fannys@fe.untar.ac.id
}

Masuk : 11-03-2020, revisi: 15-04-2020, diterima untuk diterbitkan : 15-04-2020

\begin{abstract}
ABSTRAK
Tujuan penelitian ini bertujuan untuk mengetahui dan menganalisis pengaruh intellectual capital (human capital efficiency, capital employed efficiency, structural capital efficiency) dan ukuran perusahaan terhadap kinerja keuangan perusahaan. Metode penelitian yang digunakan adalah regresi data panel dengan teknik pengambilan sampel purposive sampling yang menghasilkan jumlah sampel sebanyak 64 perusahaan yang terdaftar di Bursa Efek Indonesia (BEI). Penelitian ini dilakukan dengan menggunakan tahun pengamatan yaitu 2015-2017. Jenis data yang digunakan adalah data sekunder. Data diperoleh dari laporan keuangan yang diambil dari www.idx.com. Penelitian ini dibantu dengan program software eviews 9. Hasil penelitian ini membuktikan bahwa Intellectual capital yang diukur dengan Capital employed efficiency (VACA) berpengaruh positif signifikan terhadap kinerja keuangan perusahaan manufaktur. Pengukuran intellectual capital yang diukur dengan Human capital efficiency (VAHU) berpengaruh positif terhadap kinerja keuangan perusahaan. Pengukuran intellectual capital yang diukur structural capital efficiency yang berpengaruh positif terhadap kinerja keuangan perusahaan. Dan ukuran perusahaan manufaktur tidak berpengaruh terhadap kinerja keuangan perusahaan.
\end{abstract}

Kata Kunci: Kinerja keuangan, Intellectual capital, dan Ukuran perusahaan

\begin{abstract}
The purpose of this study aims to determine and analyze the effect of intellectual capital (human capital efficiency, capital employed efficiency, structural capital efficiency) and company size on the company's financial performance. The research method used is panel data regression with purposive sampling technique that produces a total sample of 64 companies listed on the Indonesia Stock Exchange (IDX). This research was conducted using observation years 2015-2017. The type of data used is secondary data. Data obtained from financial reports taken from www.idx.com. This research was assisted with a software eviews 9. The results of this study prove that Intellectual capital as measured by Capital employed efficiency (VACA) has a significant positive effect on the financial performance of manufacturing companies. Intellectual capital measurement as measured by Human capital efficiency (VAHU) has a positive effect on the company's financial performance. Intellectual capital measurement that is measured structural capital efficiency that affects the company's financial performance. And the size of the manufacturing company has no effect on the company's financial performance.
\end{abstract}

Keywords: Financial performance, Intellectual capital, and size.

\section{PENDAHULUAN}

\section{Latar Belakang}

Naik turunnya perekonomian pada tingkat mikro tercermin dari kinerja keuangan perusahaanperusahan yang terdaftar di bursa efek. Menurut data yang diperoleh dari BEI, terdapat beberapa emiten yang mengalami penurunan laba bersih pada periode 2018. Salah satu emiten tersebut ialah PT. Astra Agro Lestari Tbk (AALI) yang merilis penurunan laba bersihnya pada akhir periode 2017 sebesar 27\% dari Rp 1,96 triliun menjadi Rp 1,43 triliun pada akhir periode 2018 (https://investasi.kontan.co.id). Penurunan laba bersih juga dialami oleh PT. PP (Persero) Tbk (PTPP) pada kuartal III-2018 mengalami penurunan sebesar Rp 874,67 miliar. Angka tersebut menurun sebesar 11,64\% dari laba bersih yang diperoleh di periode sama tahun lalu sebesar Rp 
989,98 miliar (https://finance.detik.com). Penurunan laba bersih seperti uraian di atas, dapat menimbulkan kekhawatiran pemegang saham akan distribusi laba perusahaan kepada mereka. Dibutuhkan usaha yang lebih keras dari para manajemen perusahaan untuk dapat meningkatkan kinerja keuangan perusahannya sehingga dapat menjadi lebih baik yang tercermin dari keuntungan (laba) yang dicapai oleh perusahaan (Fahmi, 2012: 2).

Mengacu pada penelitian-penelitian sebelumnya, terdapat beberapa faktor yang mampu mempengaruh kinerja keuangan suatu perusahaan antara lain liquidity ratio, operating ratio, leverage ratio, firm size, kebijakan hutang. Faktor tersebut dapat dilihat dari laporan keuangan perusahaan maupun dari analisis laporan keuangan tersebut. Faktor-faktor yang telah diuraikan di atas dirasakan oleh perusahaan belum memadai untuk menjamin kelangsungan hidup perusahaan dalam jangka panjang. Ada faktor lain seperti intelectual capital yang menjadi faktor penentu suksesnya sebuah perusahaan. Intellectual capital atau disebut juga modal intelektual merupakan aset tak berwujud yang dimiliki oleh suatu perusahaan. Intellectual capital sangat penting diterapkan pada perusahaan di era globalisasi saat ini karena banyak perusahaan yang mulai mengimplementasikan usaha menggunakan sains daripada melakukan usaha berbasis tenaga. Pemanfaatan dan kontribusi intellectual capital yang signifikan dapat menciptakan nilai tambah bagi suatu industri sehingga diharapkan mampu menumbuhkan kinerja keuangan perusahaan.

Hasil penelitian Fathi et al. (2013); Al-Musali et al.((2014); Nimtrakoon (2015); Nawaz dan Haniffa (2017) menemukan bahwa kinerja keuangan dapat dipengaruhi oleh intellectual capital, yakni intellectual capital berpengaruh positif terhadap kinerja keuangan suatu perusahaan. Temuan ini sejalan dengan penelitian Dzenopoljac et al. (2016). Akan tetapi berbeda dengan hasil penelitian yang dibuktikan oleh Daud \& Amri (2008) yang menunjukkan bahwa adanya pengaruh negatif dan signifikan intellectual capital terhadap kinerja keuangan perusahaan. Hasil penelitian tersebut didukung oleh hasil riset Kuryanto dan Syafruddin (2008) menunjukkan bahwa Intellectual Capital (IC) tidak berpengaruh positif terhadap kinerja keuangan perusahaan.

Selain intellectual capital, faktor lain yang dapat mempengaruhi kinerja keuangan yakni besar kecil perusahaan (ukuran perusahaan). Penelitian Babalola (2013); John and Adebayo (2013); Aprianingsih dan Yushita (2016) berpendapat bahwa ukuran perusahaan memiliki pengaruh positif terhadap kinerja keuangan. Alasannya adalah ukuran perusahaan yang lebih besar dapat memberikan informasi yang lebih baik untuk kepentingan investasi, karena perusahaan yang besar akan lebih diperhatikan oleh masyarakat sehingga dalam melakukan pelaporan akan lebih hati-hati. Sedangkan menurut hasil riset Yuqi (2007), apabila ukuran perusahaan sangat besar dapat berpengaruh negatif terhadap kinerja keuangan karena alasan birokrasi dan lainnya. Sependapat dengan hasil riset Yuqi adalah Isabanah (2015) yang menyatakan kecil besarnya perusahaan menurunkan kinerja keuangan perusahaan. Akan tetapi Omondi dan Muturi (2013); Tambunan dan Prabawani (2018) yang menyatakan hasil riset mereka yang berbeda bahwa besar kecilnya perusahaan tidak berpengaruh signifikan terhadap kinerja keuangan, alasannya adalah besar aset yang tercatat dalam neraca tidak dijalankan dengan efisien sehingga tidak menyebabkan keuntungan yang tinggi untuk perusahaan.

Menurut hasil riset yang dijabarkan diatas, disimpulkan bahwa hasil riset mengenai intellectual capital dan ukuran perusahaan tidak konsisten dmemberikan efek terhadap kinerja keuangan perusahaan. Sehingga alasan inilah yang memotivasi peneliti ingin menguji kembali pengaruh intellectual capital dan ukuran perusahaan terhadap kinerja keuangan perusahaan. Riset ini ditujukan untuk membuktikan secara empiris bagaimana pengaruh intellectual capital terhadap 
kinerja keuangan perusahaan, dan bagaimana besar kecilnya perusahaan berpengaruh terhadap kinerja keuangan perusahaan.

\section{Rumusan Masalah}

Berlandaskan uraian masalah penelitian diatas, pertanyaan peneliti yang diajukan sebagai berikut:

1) Apakah intellectual capital berpengaruh positif terhadap kinerja keuangan perusahaan?

2) Apakah ukuran perusahaan berpengaruh positif terhadap kinerja keuangan perusahaan?

\section{Tinjauan Pustaka}

Kinerja keuangan artinya sebagai suatu hasil atau prestasi yang berhasil didapatkan oleh manajemen perusahaan untuk menjalankan fungsinya dalam mengelola aset yang ada di perusahaan dengan efektif selama periode tertentu (Rudianto, 2013). Isbanah mendefinisikan kinerja keuangan perusahaan adalah alat ukur keberhasilan seorang manajer dalam menjalankan perusahaannya (2015). Informasi berhubungan dengan kinerja keuangan dibutuhkan oleh pihakpihak yang berkepentingan dengan perusahaan. Riset ini menyimpulkan bahwa kinerja keuangan adalah suatu alat pengukuran yang dimiliki oleh suatu perusahaan agar tercapainya tujuan perusahaan tersebut sehingga perusahaan dapat mewujudkan competitive advantage nya.

Stewart (Setiawan dan Prawira, 2018) berpendapat bahwa intellectual capital adalah aset tidak berwujud perusahaan, yang dapat menjadi pengetahuan, informasi, pengalaman sumber daya manusia dan organisasi perusahaan. Menurut Barney (Komnenic dan Pokrajcic, 2012) intellectual capital sangat berharga, sulit untuk ditiru dan langka. Maka dari itu, intellectual capital diperlakukan seperti aset strategis yang dapat menghasilkan competitive advantage secara berkelanjutan. Intellectual capital di ukur dengan tiga pengukuran yaitu Capital Employed Efficiency (VACA), Human Capital Efficiency (VAHU), dan Structural Capital Efficiency (STVA) (Wijayani, 2017). VACA ialah hubungan yang baik dan berkelanjutan antara perusahaan dan pihak lain, yaitu diantaranya pemasok, distributor, masyarakat dan pemerintah. VAHU ialah kualitas sumber daya manusia (SDM) yang ada di dalam suatu perusahaan seperti pengalaman, pengetahuan, keterampilan, dan hubungan kerja yang selaras di dalam atau di luar perusahaan. STVA berhubungan dengan rangkaian proses, struktur organisasi, budaya kerja maupun kemampuan perusahaan untuk memenuhi kegiatannya dan strategi (Wijayani, 2017). Ukuran perusahaan adalah skala yang mengklasifiskasikan besar kecilnya perusahaan berdasarkan total asset, harga saham, dan sebagainya (Putra dan Lestari, 2016).

Resource-Based View Theory menyatakan bahwa sumber daya internal dari perusahaan jauh lebih penting daripada faktor-faktor eskternalnya dalam rangka mencapai competitive advantage (David \& David, 2015, p. 191-192). Menurut Komenic dan Pokrajcic (2012) dalam penelitiannya berpendapat bahwa berdasarkan teori ini, perusahaan akan mencapai competitive advantage dengan menggunakan dan memperoleh intangible asset. Hubungan antara Resource-Based ViewTheory dan intellectual capital ada pada pemanfaatan dari intellectual capital itu sendiri. Intellectual capital merupakan kategori dari teori Resource-Based View yang dengan sebaikbaiknya akan menyebabkan suatu perusahaan mencapai keunggulan bersaing berkelanjutan.

Agency Theory pertama kali diperkenalkan oleh Jensen dan Meckling tahun 1976 adalah teori yang melandasi kinerja keuangan suatu perusahaan. Menurut Ehikioya (2009) pada penelitiannya, menjelaskan adanya sebuah konflik kepentingan antara principal (investor atau pemegang saham) dan agent (manajer) sehingga dinamakan dengan masalah agensi. Masalah agensi yang dapat dikurangi atau bahkan dihilangkan, akan meningkatkan kinerja keuangan 
perusahaan. Menurut Jackling dan Johl (2009) teori agensi ini dapat digunakan untuk memeriksa dan mengawasi peran yang dimainkan oleh direktur perusahaan atas keterlibatannya terhadap kinerja keuangan perusahaan yang dikelola.

\section{Hipotesis Penelitian}

Pengertian dari capital employed sendiri adalah hubungan antara perusahaan tersebut dengan lingkungan eskternalnya. Beberapa contoh dari lingkungan eskternal perusahaan yaitu seperti distributor, customer, supplier dan juga investor. Perusahaan harus menjaga hubungan yang sebaik mungkin dengan pihak eksternalnya, karena hal ini dapat menentukan penilaian mereka terhadap perusahaan kita. Jadi, apabila tercipta hubungan yang baik antara perusahaan dengan pihak eksternal, memungkinkan untuk pihak eksternal tersebut memberikan penilaian lebih terhadap perusahaan. Sehingga penilaian yang baik tersebut dapat meningkatkan kinerja keuangan perusahaan. Penelitian Setiawan dan Prawira (2018) dan Dzenopoljac et al. (2016) membuktikan bahwa adanya pengaruh positif antara Capital Employed Efficiency (VACA) dengan kinerja keuangan perusahaan. Berdasarkan penjelasan diatas dapat dirumuskan hipotesisnya yaitu:

H1a: Capital employed efficiency (VACA) berpengaruh positif terhadap kinerja keuangan perusahaan.

Pengertian dari human capital adalah pengetahuan-pengetahuan lebih yang dimiliki oleh karyawan perusahaannya. Kemampuan tersebut dapat meliputi pengalaman bekerja sebelumnya, kemampuan dalam bekerja sama antar karyawan, kreativitas, berinovasi, motivasi dan fleksibilitas karyawan. Apabila perusahaan dapat mengaplikasikan serta memanfaaatkan pengetahuan yang dimiliki karyawannya dengan sebaik mungkin, maka human capital employed dapat efektif. Pemanfaatan human capital yang efektif, dapat memberikan peningkatan pada kinerja keuangan industri. Penelitian Fathi et al. (2013) membuktikan bahwa terdapat dampak positif antara Human Capital Efficiency (VAHU) dengan kinerja keuangan perusahaan. Berdasarkan penjelasan diatas dapat dirumuskan hipotesis kedua yaitu:

H1b: Human capital efficiency (VAHU) berpengaruh positif terhadap kinerja keuangan perusahaan.

Pengertian dari structural capital efficiency adalah kemampuan industri gunamenaikkan kinerja keuangan industri tersebut, melalui software maupun hardware, dan bisa juga sebagai sarana prasarana yang dapat mendukung kinerja karyawan perusahaan. Seorang karyawan perusahaan yang memiliki intelektualitas tinggi menjadi percuma apabila tidak didukung oleh sistem dan sarana yang menunjang. Tetapi, apabilaindustrimempunyai sistem dan sarana yang mendukung dan dimanfaatkan dengan sebaik mungkin oleh para karyawan, maka kinerja keuangan industri akan tumbuh optimal. Penelitian Setiawan dan Prawira (2018) membuktikan bahwa adanya pengaruh positif antara structural capital efficiency (STVA)dengan kinerja keuangan perusahaan. Berdasarkan penjelasan diatas dapat dirumuskan hipotesis ketiga yaitu:

H1c: Structural capital efficiency (STVA)berpengaruh positif terhadap kinerja keuangan perusahaan.

Ukuran perusahaan dilihat dari total aset yang dimiliki oleh perusahaan atau total aset perusahaan yang tercantum dalam laporan keuangan perusahaan selama akhir periode audit (Agnes, 2011). Penelitian Babalola (2013); John and Adebayo (2013); Aprianingsih dan Yushita (2016) berpendapat bahwa ukuran perusahaan memiliki pengaruh positif terhadap kinerja keuangan. Alasannya adalah ukuran perusahaan yang lebih besar dapat memberikan informasi yang lebih baik untuk kepentingan investasi, karena perusahaan yang besar akan lebih 
diperhatikan oleh masyarakat sehingga dalam melakukan pelaporan akan lebih hati-hati. Sehingga hipotesis yang diajukan dalam riset adalah:

$\mathrm{H} 2$ : Ukuran perusahan berpengaruh positif terhadap kinerja keuangan perusahaan

\section{METODE PENELITIAN}

Populasi yang digunakan di dalam penelitian ini adalah seluruh perusahaan manufaktur periode 2015-2017 yang terdaftar di Bursa Efek Indonesia (BEI). Sampel yang digunakan adalah seluruh perusahaan manufaktur periode 2015-2017 yang terdaftar di Bursa Efek Indonesia (BEI) dengan teknik pengambilan sample metode purposive sampling, dengan tujuan agar memperoleh sampel selaras dengan kriteria yang telah ditetapkan. Kriteria nya adalah (1) Terdaftar di BEI secara terus menerus dalam kurun periode 2015-2017; (2) Tidak mengalami kerugian dalam kurun periode 2015-2017; (3) Laporan keuangannya menggunakan mata uang rupiah (simbol: IDR); (4) Tidak melakukan merger; (5) Tidak melakukan IPO dalam kurun periode 2015-2017. Hasil akhir sampel penelitian berdasarkan kriteria sebanyak 192 observasi.

Operasionalisasi Variabel

\begin{tabular}{lc}
\hline \multicolumn{1}{c}{ Variabel } & Pengukuran \\
\hline 1. Variabel Terikat & $\frac{\text { Net income }}{\text { Total assets }}$ \\
\hline Kinerja keuangan (ROA) & $\frac{\text { Value added }}{\text { Capital employed }}$ \\
\hline 2. Variabel Bebas & $\frac{\text { Value added }}{\text { Human capital }}$ \\
\hline Capital Employed Efficiency & $\frac{\text { Structur capital }}{\text { Value Added }}$ \\
\hline Human Capital Efficiency & \multicolumn{1}{l}{$\begin{array}{l}\text { Variabel ini dihitung dengan menggunakan } \\
\text { proxy logaritma dari nilai kapitalisasi } \\
\text { perusahaan. }\end{array}$} \\
\hline Structural capital Efficiency & \\
\hline Ukuran Perusahaan (Size) &
\end{tabular}

\section{Kinerja keuangan (ROA)}

Isbanah mendefinisikan kinerja keuangan perusahaan adalah alat ukur keberhasilan seorang manajer dalam menjalankan perusahaannya (2015). Di beberapa riset, kinerja keuangan diukur menggunakan return on asset (ROA), dengan alasan mampu untuk mengukur kemampuan perusahaan dalam menghasilkan laba dalam kegiatan operasi, dimana besarnya laba yang dihasilkan mencerminkan kinerja keuangan yang baik sehingga perusahaan dikatakan mampu memenuhi kewajiban kepada kreditur dan investor (Rachmawati, 2012; Isbanah, 2013). Apabila semakin tinggi rasio tersebut berarti menunjukkan adanya efisiensi yang dilakukan oleh para manajemen perusahaan sehingga bisa meningkatkan kinerja perusahaaan tersebut terutama kinerja keuangan (Gitman et al., 2012: 81; Akbar, 2013). Oleh karena itu penelitian ini menggunakan ROA sebagai proksi pengukur kinerja keuangan perusahaan.

\section{Intellectual Capital}

Riset ini mengukur IC perusahaan manufaktur di Indonesia menggunakan metode Value Added Intellectual Coefficient (VAICTM) yang dikembangkan oleh public, dimana komponen utama dari VAIC ${ }^{\text {TM }}$ yang dikembangkan Pulic (1998) tersebut dapat dilihat dari sumber daya 
perusahaan, yaitu Value Added Capital Employed (VACA), Value Added Human Capital (VAHU) dan Structural Capital Value Added (STVA).

\section{Ukuran Perusahaan}

Besar kecilnya perusahaan yang diukur dengan total asset yang dimiliki berpengaruh terhadap kinerja keuangan perusahaan tersebut (Isbanah, 2015). Senada dengan hasil riset Isbanah, Wright et al. (2009) menemukan bahwa ukuran perusahaan berpengaruh positif terhadap kinerja. Jadi, semakin besar ukuran perusahaan, semakin bagus kinerja keuangannya

Berdasarkan penjelasan diatas, model penelitian yang diajukan dalam riset adalah sebagai berikut:

$$
\text { ROAit }=\text { ait + bVACAit +cVAHUit + dSTVAit+eSizeit }+e i t
$$

Keterangan:

$\mathrm{a}=$ Konstanta

ROA = Kinerja keuangan perusahaan

VACA = Capital Employed Efficiency

VAHU = Human Capital Efficiency

STVA = Structural Capital Efficiency

Size $=$ Ukuran perusahaan

$\mathrm{i}=$ perusahaan/ obervasi

$\mathrm{t}=$ periode penelitian

$\mathrm{e}=$ error

\section{HASIL DAN PEMBAHASAN}

\section{Statistik Deskriptif}

\begin{tabular}{lccccc}
\multicolumn{5}{c}{ Statistik Deskrptif untuk Model Penelitian } \\
\hline Mean & ROA & VACA & VAHU & STVA & SIZE \\
\hline Median & 0.090474 & 0.345049 & 4.412585 & 0.679668 & 25.13726 \\
\hline Maximum & 0.063150 & 0.284900 & 3.547100 & 0.718050 & 28.20515 \\
\hline Minimum & 0.781400 & 2.103400 & 19.62840 & 0.949100 & 285228.0 \\
\hline Std. Dev. & 0.000200 & 0.043300 & 1.253100 & 0.202000 & 0.016500 \\
\hline Skewness & 0.104273 & 0.311496 & 3.014308 & 0.174687 & 20582.51 \\
\hline Kurtosis & 3.167985 & 3.590113 & 1.986824 & -0.667148 & 13.74792 \\
\hline \multicolumn{7}{c}{18.60903} & 8.265657 & 2.637811 & 190.0052 \\
\hline Jarque-Bera & 16.61639 & & & \\
\hline Probability & 1804.406 & 2361.580 & 348.1362 & 15.29223 & 285815.8 \\
\hline \multicolumn{7}{c}{0.000000} & 0.00000 & 0.000000 & 0.000478 & 0.000000 \\
\hline Sum & 17.37100 & 66.24950 & 847.2164 & 130.4962 & 290635.3 \\
\hline Sum Sq. Dev. & 2.076731 & 18.53271 & 1735.436 & 5.828439 & $8.09 E+10$ \\
\hline \multicolumn{7}{c}{10} \\
\hline Observations & 192 & & & 192 \\
\hline
\end{tabular}

Berdasarkan hasil pengujian statistik deskriptif, menunjukkan bahwa rata-rata perusahaan manufaktur memiliki kinerja keuangan yang diukur oleh ROA sebesar 9,04\%, mengartikan bahwa memiliki kinerja keuangan yang rendah dikarenakan nilai intellectual capitalnya rendah. Sedangkan menurut rata-rata ukuran perusahaan sebesar 25,1327 , mengartikan bahwa besarnya ukuran perusahaan belum dipastikan kinerja keuangan perusahaan baik. 
Ukuran VACA berdasarkan statistik deskriptif diatas diperoleh rata-rata sebesar $34,5 \%$ dengan nilai VACA terkecil adalah sebesar $4,3 \%$ dan $210 \%$. Sedangan ukuran VAHU rata-ratanya adalah 4,41 dengan nilai maksimum sebesar 19,62. Dan proksu pengukuran intellectual capital terakhir yaitu STVA memiliki nilai rata-rata sebesar 67,96\% dengan nilai maksimum 94,91\%.

\section{Hasil Uji Asumsi Klasik}

Uji asumsi klasik meliputi empat hal yaitu pengujian terhadap masalah normalitas, multikolinearitas, heteroskedastisitas, dan autokorelasi. Berdasarkan data panel, dari semua uji asumsi klasik yang dilakukan, hanya uji normalitas dengan hasil data penelitian adalah normal, sedangkan menurut Gujarati dan Porter (2009) dan Ekananda (2016), uji asumsi klasik pada regresi data panel tidak perlu dilakukan dengan alasan bahwa data panel memiliki keunggulan yang sudah dijelaskan di bab metode penelitian. Sehingga dapat disimpulkan bahwa penelitian ini dapat dilanjutkan ke pengujian hipotesis.

\section{Analisis Data Panel}

Pertama-tama data panel diesmitasi menggunakan efek spesifikasi fixed. Uji yang dilakukan yaitu uji Chow. Uji ini bertujuan untuk mengetahui apakah sebaiknya model menggunakan fixed effect atau common effect.

Ho: Common Effect

Ha: Fixed Effect

Apabila hasil probabilitas chi-square kurang dari 5\%, maka ditolak. Sehingga, model menggunakan fixed effect. Hasil dari estimasi menggunakan efek spesifikasi fixed adalah sebagai berikut:

\begin{tabular}{|l|c|}
\hline \multicolumn{1}{|c|}{ Effect Test } & Probabilitas \\
\hline Cross-section F & 0,0000 \\
\hline Cross-section Chi-Square & 0,0000 \\
\hline Sumber : Output Eviews 9
\end{tabular}

Berdasarkan hasil di atas, diketahui probabilitas Chi-square sebesar 0,0000 sehingga menyebabkan ditolak. Maka model fixed adalah model yang sebaiknya digunakan dibandingkan common effect.

Pengujian selanjutnya adalah Hausman Test, dimana bertujuan untuk mengetahui apakah model random effect lebih baik digunakan dari fixed effect.

Ho: Random Effect

Ha: Fixed Effect

Apabila hasil probabilitas chi-square lebih dari 5\%, maka sebaiknya model menggunakan random effect. Hasil dari estimasi menggunakan efek spesifikasi random adalah sebagai berikut:

\begin{tabular}{|c|c|c|}
\hline Test Summary & Chi-Sq. Statistic & Probabilitas \\
\hline Cross-section random & 10,527623 & 0,0416 \\
\hline
\end{tabular}

Sumber : Output Eviews 9

Hasil probabilitas chi-square sebesar 0,0416. Sehingga dapat disimpulkan bahwa model sebaiknya menggunakan menunjukkan fixed effect lebih tepat daripada random effect. 


\section{Hasil Analisis Data}

Dari uji spesifikasi di atas, maka model sebaiknya menggunakan estimasi dengan fixed effect. Hasil estimasi model regresi data panel adalah sebagai berikut:

\begin{tabular}{crrr}
\multicolumn{5}{c}{$\begin{array}{c}\text { Hasil Estimasi Model } \\
\text { Sumber : Output Eviews } 9\end{array}$} \\
\hline Variabel & Koefisien & t-statistik & Probabilitas \\
\hline C & $-0,085580$ & $-2,741733$ & 0,0070 \\
\hline VACA & 0,159322 & 3,489722 & 0,0007 \\
\hline VAHU & 0,011535 & 2,860688 & 0,0050 \\
\hline STVA & 0,103411 & 1,811479 & 0,0725 \\
\hline SIZE & $-1,37 \mathrm{E}-08$ & $-0,090703$ & 0,9279 \\
\hline R-squared & 0,928159 & Mean dependent var & 0,090474 \\
\hline Adjusted & & & 0,104273 \\
R-squared & 0,888443 & S.D. dependent var & 2,953934 \\
\hline F-statistic & 23,36950 & Durbin-Watson stat & \\
\hline Prob (F-statistic) & 0,000000 & & \\
\hline
\end{tabular}

Dari hasil pengolahan data panel dengan metode fixed effect diperoleh persamaan regresi sebagai berikut:

$$
\text { ROA }=-0,0855+0,1593 \text { VACA + 0,0115VAHU + 0,01034STVA + 0,0000UP }
$$

Persamaan regresi data panel di atas dapat diketahui bahwa koefisien konstanta sebesar 0,0855menunjukkan bahwa terdapat variabel sistematis lain yang juga mempengaruhi akan tetapi tidak masuk dalam model. Koefisien dari variabel-variabel tersebut secara akumulasi bernilai negatif. Karena tidak masuk dalam model, angka-angka sistematis tersebut masuk ke dalam konstanta. Sehingga menyebabkan koefisien konstanta menjadi negatif.

Koefisien determinasi atau goodness of fit diperoleh angka sebesar 0,92851. Hal ini berarti bahwa kontribusi seluruh variabel bebas dalam menjelaskan variabel terikat sebesar 92,851\%. Sisanya sebesar 7,149\% dijelaskan oleh variabel lain di luar model penelitian.

\section{Pembahasan}

Berdasarkan hasil pengujian regresi data panel dibuktikan bahwa hipotesis 1a diterima, ini mengartikan bahwa VACA berpengaruh positif terhadap kinerja keuangan perusahaan. Perusahaan harus menjaga hubungan yang sebaik mungkin dengan pihak eksternalnya, karena hal ini dapat menentukan penilaian mereka terhadap perusahaan kita. Jadi, apabila tercipta hubungan yang baik antara perusahaan dengan pihak eksternal, memungkinkan untuk pihak eksternal tersebut memberikan penilaian lebih terhadap perusahaan. Sehingga penilaian yang baik tersebut dapat meningkatkan kinerja keuangan perusahaan. Hasil penelitian ini didukung oleh penelitian Setiawan dan Prawira (2018); Dzenopoljac et al. (2016) membuktikan bahwa adanya pengaruh positif antara VACA dengan kinerja keuangan perusahaan.

Hasil dari pengujian regresi data panel membuktikan bahwa hipotesis $1 \mathrm{~b}$ diterima, yang mengartikan human capital efficiency berpengaruh positif signfikan terhadap kinerja keuangan perusahaan. Pengetahuan akan pekerjaan, pengalaman bekerja sebelumnya, kemampuan dalam bekerja sama antar karyawan, kreativitas, berinovasi, motivasi dan fleksibilitas karyawan adalah bagian dari human capital efficiency dari seorang karyawan, apabila diaplikasikan dan dimanfaaatkan pengetahuan yang dimiliki karyawannya dengan sebaik mungkin, maka human 
capital employed dapat efektif. Pemanfaatan human capital yang efektif, dapat memberikan peningkatan pada kinerja keuangan perusahaan. Hasil penelitian ini didukung oleh penelitian Fathi et al. (2013) membuktikan bahwa terdapat dampak positif antara VAHU dengan kinerja keuangan perusahaan.

Hasil pengujian statistik regresi data panel membuktikan bahwa hipotesis 1c diterima, yang mengartikan bahwa structural capital efficiency (STVA) berpengaruh positif signifikan terhadap kinerja keuangan. STVA adalah kemampuan industri guna menaikkan kinerja keuangan industri tersebut, melalui software maupun hardware, dan bisa juga sebagai sarana prasarana yang dapat mendukung kinerja karyawan perusahaan yang pada akhirnya mempengaruhi kinerja keuangan perusahaan. Hasil penelitian ini didiukung oleh penelitian Setiawan dan Prawira (2018) membuktikan bahwa adanya pengaruh positif antara STVA dengan kinerja keuangan perusahaan.

Hasil regresi data panel menyimpulkan bahwa hipotesis 2 ditolak, yang mengartikan besar kecilnya perusahaan tidak berpengaruh terhadap kinerja keuangan perusahaan. Artinya calon investor sangat memahami bahwa ukuran perusahaan tidak bisa digunakan sebagai jaminan bahwa perusahaan yang besar memiliki kinerja keuangan yang bagus karena perusahaan yang besar belum tentu didukung oleh pengelolaan yang bagus (Isbanah, 2015). Hasil ini sejalan dengan Talebria et al. (2010) dan Tambunan dan Prabwani (2018) yang juga menemukan bahwa tidak terdapat pengaruh ukuran perusahaan terhadap kinerja keuangan perusahaan.

\section{KESIMPULAN DAN SARAN}

Berlandaskan tujuan penelitian yaitu untuk membuktikan secara empiris bagaimana pengaruh intellectual capital dan ukuran perusahaan terhadap kinerja keuangan perusahaan. Penelitian ini telah membuktikan bahwa intellectual yang diukur dengan Capital employed efficiency (VACA) berpengaruh positif signifikan terhadap kinerja keuangan perusahaan manufaktur. Hasil penelitian mengindikasikan bahwa perusahaan harus menjaga hubungan yang sebaik mungkin dengan pihak eksternalnya, karena hal ini dapat menentukan penilaian mereka terhadap perusahaan kita. Jadi, apabila tercipta hubungan yang baik antara perusahaan dengan pihak eksternal, memungkinkan untuk pihak eksternal tersebut memberikan penilaian lebih terhadap perusahaan. Sehingga penilaian yang baik tersebut dapat meningkatkan kinerja keuangan perusahaan. Pengukuran intellectual capital yang diukur dengan Human capital efficiency (VAHU) berpengaruh positif terhadap kinerja keuangan perusahaan. Pengetahuan akan pekerjaan, pengalaman bekerja sebelumnya, kemampuan dalam bekerja sama antar karyawan, kreativitas, berinovasi, motivasi dan fleksibilitas karyawan adalah bagian dari human capital efficiency dari seorang karyawan, apabila diaplikasikan dan dimanfaaatkan pengetahuan yang dimiliki karyawannya dengan sebaik mungkin, maka human capital employed dapat efektif. Pemanfaatan human capital yang efektif, dapat memberikan peningkatan pada kinerja keuangan perusahaan. Proksi pengukuran terakhir dari intellectual capital adalah structural capital efficiency (STVA) yang berpengaruh positif terhadap kinerja keuangan perusahaan. Structural capital efficiency adalah kemampuan industri guna menaikkan kinerja keuangan industri tersebut, melalui software maupun hardware, dan bisa juga sebagai sarana prasarana yang dapat mendukung kinerja karyawan perusahaan yang pada akhirnya mempengaruhi kinerja keuangan perusahaan.

Hasil regresi data panel menyimpulkan bahwa ukuran perusahaan yang diukur dengan besar kecilnya assets tidak berpengaruh terhadap kinerja keuangan. Alasannya karena ukuran perusahaan yang diukur dengan assets, belum tentu perusahan menyajikan nilai assets yang sebenarnya. Hal tersebut berdampak bahwa nilai assets yang besar belum menjadi jaminan atas 
kinerja keuangan perusahaan yang baik yang memberikan keuntungan bagi investor. bagus (menghasilkan laba besar yang meningkat setiap tahunnya). Adapun perbandingan hasil riset dapat dilihat dalam tabel dibawah ini:

\begin{tabular}{|c|c|c|}
\hline Hipotesis Penelitian & Hasil Penelitian & Hasil Penelitian Sebelumnya \\
\hline $\begin{array}{l}\text { H1a: VACA berpengaruh } \\
\text { positif terhadap kinerja } \\
\text { keuangan perusahaan }\end{array}$ & $\begin{array}{l}\text { VACA berpengaruh } \\
\text { positif signifikan terhadap } \\
\text { kinerja keuangan } \\
\text { perusahaan manufaktur }\end{array}$ & $\begin{array}{l}\text { - Hasil riset Fathi et al. (2013) yang menyatakan } \\
\text { VACA berpengaruh positif signifikan terhadap } \\
\text { kinerja keuangan perusahaan manufaktur } \\
\text { - Hasil riset Oktavia dan Fuad (2015) VACA } \\
\text { tidak berpengaruh terhadap kinerja keuangan } \\
\text { perusahaan }\end{array}$ \\
\hline $\begin{array}{l}\text { H1b: VAHU berpengaruh } \\
\text { positif terhadap kinerja } \\
\text { keuangan perusahaan. }\end{array}$ & $\begin{array}{l}\text { VAHU berpengaruh } \\
\text { positif terhadap kinerja } \\
\text { keuangan perusahaan. }\end{array}$ & $\begin{array}{l}\text { - Hasil riset Fathi et al. (2013) yang menyatakan } \\
\text { VAHU berpengaruh positif signifikan } \\
\text { terhadap kinerja keuangan perusahaan } \\
\text { manufaktur } \\
\text { - Hasil riset Andriana (2014) menyatakan } \\
\text { VAHU tidak berpengaruh signifikan terhadap } \\
\text { kinerja keuangan }\end{array}$ \\
\hline $\begin{array}{l}\text { H1c: STVA berpengaruh } \\
\text { positif terhadap kinerja } \\
\text { keuangan perusahaan }\end{array}$ & $\begin{array}{l}\text { STVA berpengaruh } \\
\text { positif terhadap kinerja } \\
\text { keuangan perusahaan }\end{array}$ & $\begin{array}{l}\text { - Hasil riset Fathi et al. (2013) yang menyatakan } \\
\text { STVA berpengaruh positif signifikan terhadap } \\
\text { kinerja keuangan perusahaan manufaktur } \\
\text { - Maditinos et al. (2011) yang menyatakan } \\
\text { STVA tidak berpengaruh terhadap kinerja } \\
\text { keuangan perusahaan } \\
\text { - Hasil riset Oktavia dan Fuad (2015) STVA } \\
\text { tidak berpengaruh terhadap kinerja keuangan } \\
\text { perusahaan }\end{array}$ \\
\hline $\begin{array}{l}\text { H2: Ukuran perusahaan } \\
\text { berpengaruh positif } \\
\text { terhadap kinerja keuangan } \\
\text { perusahaan. }\end{array}$ & $\begin{array}{l}\text { Ukuran perusahaan yang } \\
\text { diukur dengan besar } \\
\text { kecilnya assets tidak } \\
\text { berpengaruh terhadap } \\
\text { kinerja keuangan }\end{array}$ & $\begin{array}{l}\text { - Hasil riset Isabanah (2015) yang menyatakan } \\
\text { ukuran perusahaan berpengaruh negatif } \\
\text { terhadap kinerja keuangan. } \\
\text { - Hasil riset Wright et al. (2009), yaitu } \\
\text { menyimpulkan bahwa ukuran perusahaan } \\
\text { berpengaruh positif terhadap kinerja. } \\
\text { - Hasil riset Tambunan dan Prabawani (2018); } \\
\text { Telebria et al. (2010) yang menyatakan besar } \\
\text { kecilnya perusahaan tidak berpengaruh } \\
\text { signifikan terhadap kinerja keuangan. }\end{array}$ \\
\hline
\end{tabular}

Penelitian ini memberikan saran-saran untuk penelitian selanjutnya untuk dilakukan adalah (1) penelitian selanjutnya dapat menggunakan pengukuran lain dalam mengukur kinerja keuangan perusahaan yaitu menggunakan net profit margin (NPM); (2) penelitian selanjutnya dapat mengganti sampel penelitian yaitu industri perbankan dan jasa sehingga hasil penelitian dapat dibandingkan dengan hasil penelitian ini; dan (3) mengganti pengukuran intellectual capital dengan ukuran eksternal yaitu market-to-book value.

\section{Ucapan Terima Kasih}

Ucapan terima kasih ditujukan kepada Tuhan YME dan berbagai pihak yang telah membantu jalannya penelitian yang sudah dilakukan. 


\section{REFERENSI}

Agnes. (2011). The Influence of Managerial Ownership, Working Capital and Company Size To Company Value. Jurnal Manajemen 2(1): 1-10. http://dx.doi.org/10.20319/pijss.2018.42.694708

Al-Musali, Mahfoudh Abdul Karem and Ku Ismail, Ku Nor Izah (2014) Intellectual capital and its effect on financial performance of banks: Evidence from Saudi Arabia. In: International Conference on Accounting Studies (ICAS), 18 - 19 August 2014, Putra World Trade Centre, Kuala Lumpur. http://dx.doi.org/10.1016/j.sbspro.2014.11.068

Andriana, Denny. (2014). Pengaruh Intellectual Capital Terhadap Kinerja Keuangan Perusahaan. Jurnal Riset Akuntansi dan Keuangan, 2(1), 251-260. https://ejournal.upi.edu/index.php/JRAK/article/download/6578/4459

Aprianingsih, Astri dan Amanita Novi Yushita. (2016). Pengaruh Penerapan GCG, Struktur Kepemilikan, dan Ukuran Perusahaan Terhadap Kinerja Keuangan Perbankan. Jurnal Profita, 4(4), $1-16$. http://journal.student.uny.ac.id/ojs/ojs/index.php/profita/article/view/5631/5378

Babalola, Yisau Abiodun. (2013). The Effect of Firm Size on Firms Profitability in Nigeria. Journal of Economics and Sustainable Development, 4(5), 90-95. http://www.academia.edu/download/31102225/4935.pdf.

Daud, Raulfah M dan Abrar Amri. (2008). Pengaruh Intellectual Capital dan Corporate Social Responsibility Terhadap Kinerja Perusahaan (Studi Pada Perusahaan Manufaktur di Bursa Efek Indonesia). Jurnal Telaah dan Riset Akuntansi,1(2), 213-231. https://media.neliti.com/media/publications/219365-none.pdf

David, F. R. \& Forest R. David, F. R.. (2015). Strategic Management: Concepts and Cases Fifteenth Edition. United States of America: Pearson

Dzenopoljac, Vladimir., Stevo Janosevic, and Nick Bontis. (2016). Intellectual capital and financial performance in the Serbian ICT industry. Journal of Intellectual Capital, 17 (2), 373-396. https://doi.org/10.1002/kpm.1404

Ekananda, Mahyus. (2016). Analisis Ekonometrika Data Panel Edisi 2. Jakarta: Mitra Wacana Media.

Ehikioya, Benjamin I.. (2009). Corporate Governance Structure and Firm Performance in Developing Economies: Evidence from Nigeria. Research Scholar based at the School of Management, 9(3), 231-243. https://doi.org/10.1108/14720700910964307

Fahmi, Irham. (2012). Analisis Laporan Keuangan. Cetakan Ke-2. Bandung: Alfabeta

Fathi, Saeed, Shekoofeh Farahmand, Mahnaz Khorasani. (2013). Impact of Intellectual Capital on Financila Performance. International Journal of Academic Research in Economies and Management Sciences, 2(1), 6-17. http://hrmars.com/admin/pics/1420.pdf

Gitman, Lawrence, J., \& Zutter, C.J. (2012). Principles of Managerial Finance. 13th Edition. Edinburgh: Pearson

Gujarati, Damodar and Dawn Porter. (2013). Dasar-dasar Ekonometrika, Buku 2. Jakarta: Salemba Empat.

Isbanah, Yuyun. (2015). Pengaruh ESOP, Leverage, dan Ukuran Perusahaan Terhadap Kinerja $\begin{array}{lllll}\text { Keuangan } & \text { Perusahaan di }\end{array}$ http://dx.doi.org/10.17970/jrem.15.150103.ID

Jackling, Beverley and Shireenjit Johl. (2009). Board Structure and Firm Performance: Evidence from India's Top Companies. An International Review, 17(4): 492-509.

https://doi.org/10.1111/j.1467-8683.2009.00760.x

John, Akinyomi Oladele and Olagunju Adebayo. (2013). Effect of Firm Size on Profitability: Evidence from Nigerian Manufacturing Sector. Prime Journal of Business Administration and Management, 3(9), 1171-1175. 
Kuryanto, B., dan Syafruddin, M. (2008). Pengaruh modal Intelektual terhadap kinerja perusahaan. Simposium Nasional Akuntansi XI. http://eprints.undip.ac.id/17133/1/SNA11Kuryanto_Syafruddin.pdf

Komnenic, Biserka and Dragana Pokrajcic. (2012). Intellectual capital and corporate performance of MNCs in Serbia. Journal of Intellectual Capital, 13(1), 106-119. https://doi.org/10.1108/14691931211196231

Maditinos, D., Chatzoudes, D., Tsairidis, C., and Theriou, G. (2011). The impact of intellectual capital on firms' market value and financial performance. Journal of Intellectual Capital, 12(1), 132-151. https://doi.org/10.1108/14691931111097944

Nawaz, Tasawar. \& Haniffa Roszaini. (2017). Determinants of financial performance of Islamic banks: an intellectual capital perspective. Journal of Islamic Accounting and Business Research, 8(2), 130-142. https://doi.org/10.1108/JIABR-06-2016-0071

Nimtrakoon, Sirinuch. (2015). The relationship between intellectual capital, firms' market value and financial performance: Empirical evidence from the ASEAN. Journal of Intellectual Capital, 16(3), 587-618. https://doi.org/10.1108/JIC-09-2014-0104

Oktavia, Theresia Margaretha dan Faud. (2105). Pengaruh Intellectual Capital terhadap kinerja keuangan dan nilai pasar perusahaan sektor keuangan di Indonesia. Diponegoro Journal of Accounting, 15(2), 1-14. https://ejournal3.undip.ac.id/index.php/accounting/article/view/15512

Omondi, Maleya M. anda Dr.Willy Muturi. (2013). Factors Affecting the Financial Performance of Listed Companies at the Nairobi Securities Exchange in Kenya. Research Journal of Finance and Accounting, 4(15), 99-104. www.iiste.org

Pulic, A. (1998). Measuring the performance of intellectual potential in knowledge economy. available at: www.vaic-on.net

Putra, AA Ngurah Dharma Adi dan Putu Vivi Lestari. (2016). Pengaruh Kebijakan Dividen, Likuiditas, Profitabilitas, dan Ukuran Perusahaan Terhadap Nilai Perusahaan. (2016). EJurnal Manajemen Unud, 5(7), 4044-4070. https://ojs.unud.ac.id/index.php/Manajemen/article/view/20373/14269

Rachmawati, Damar Asih Dwi. (2012). Pengaruh Intellectual Capital Terhadap Return on Assets Perbankan. Jurnal Nominal, 34-40. https://journal.uny.ac.id/index.php/nominal/article/view/992/795

Rudianto. (2013). Akuntansi manajemen: informasi untuk pengambilan keputusan strategis. Jakarta: Erlangga.

Setiawan, R. and Prawira, B. Y. (2018). Intellectual Capital and The Performance of Manufacturing Companies in Indonesia, 7(3), 1328. http://dx.doi.org/10.29303/jmm.v7i3.312

Talebria, Ghodratallah, Mahdi Salehi, Hashem Valipour, and Shahram Shafee. (2010). Empirical Study of the Relationship between Ownership Structure and Firm Performance: Some Evidence of Listed Companies in Tehran Stock Exchange. Journal of Sustainable Development, 3 (2), 264-270. http://dx.doi.org/10.5539/jsd.v3n2p264

Tambunan, Jessica T.A. dan Bulan Prabawani. (2018). Pengaruh Ukuran Perusahaan, Leverage, dan Struktur Modal Terhadap Kinerja Keuangan Perusahaan (Studi pada Perusahaan Manufaktur Sektor Aneka Industri Tahun 2012-2016). Jurnal Ilmu Administrasi Bisnis, 7(2), 130-140. https://ejournal3.undip.ac.id/index.php/jiab/article/view/20329.

Wijayani, Dianing Ratna. (2017). Pengaruh intellectual capital terhadap kinerja keuangan perusahaan publik di Indonesia. Jurnal Riset Akuntansi dan Bisnis Airlangga, 2(1), $97-$ 116. http://dx.doi.org/10.31093/jraba.v2i1.23 
Wright, Peter, Mark Kroll, Ananda Mukhreji, Michael L. Pettus. (2009). Do the Contingencies of External Monitoring, Ownership Incentives, or Free Cash Flow Explain Opposing Firm Performance Expectations?. Journal Management Governance, 13, 215-243. http://dx.doi.org/10.1007/s10997-008-9063-8. 